\title{
The Humanitarian Aid of the Joint Relief Commission of the International Red Cross in France to the civil population: children, women and internees (1940-1946)
}

\author{
Luiza Iordache Cârstea \\ UNED, Departamento de Historia Contemporánea \\ e-mail: luizaiordache@geo.uned.es \\ ORCID iD: https://orcid.org/0000-0001-8880-1037
}

Submitted: 18 May 2018. Accepted: 24 March 2019

\begin{abstract}
The objective of this article is the analysis of the humanitarian relief work of the International Committee of the Red Cross (ICRC) and the League of the Red Cross Societies through a joint body, the Joint Relief Committee (JRC), in France during the Second World War. Based on the treaties, convention and draft projects that shed light on the evolution and consolidation of the International Humanitarian Law relating to civilian defence and on the specialized bibliography, reports of the ICRC and the JRC, documentary sources of the ICRC Archives, and photo library of the same organization, the article focuses on humanitarian aid and priorities of the JRC in favour of the civilian population most vulnerable to and affected by war: children, women and internees in the concentration camps in South of France. This study, accompanied by photos, maps and quantitative data, sheds light on the channels of humanitarian action, the charitable organizations, associations, institutions, foundations, etc., that made this possible, as well as the loopholes and limitations of international humanitarian law, with important consequences for human life during a major conflict such as the Second World War.
\end{abstract}

KEYWORDS: Humanitarian aid; IIWW; Civilian defence; France; JRC; ICRC.

Citation / Cómo citar este artículo: Iordache Cârstea, Luiza (2019) "The Humanitarian Aid of the Joint Relief Commission of the International Red Cross in France to the civil population: children, women and internees (1940-1946)". Culture \& History Digital Journal, 8 (2): e022. https://doi.org/10.3989/chdj.2019.022

RESUMEN: La ayuda humanitaria de la Comisión Mixta de Socorro de la Cruz Roja internacional en Francia para la población civil: niños, mujeres e internados (1940-1946).- El presente artículo tiene como objetivo el análisis de la labor humanitaria desarrollada por el Comité Internacional de la Cruz Roja (CICR) y la Liga de Sociedades de la Cruz Roja a través de un organismo conjunto, la Comisión Mixta de Socorro de la Cruz Roja internacional (CMS), en Francia durante la Segunda Guerra Mundial. En base a tratados, convenciones y proyectos que arrojan luz sobre la evolución y la consolidación del Derecho Internacional Humanitario en materia de protección civil y según la bibliografía especializada, informes del CICR y de la CMS, material documental y fotográfico de los archivos del CICR, el artículo se centra en el análisis de la ayuda humanitaria de la CMS en Francia a favor de la población civil más vulnerable y afectada por la guerra, como niños, mujeres e internados en los campos de concentración del sur de Francia. Este estudio, acompañado de fotografías, mapas y datos cuantitativos de la ayuda humanitaria, nos permite arrojar luz sobre los canales de la acción humanitaria, las organizaciones caritativas, las instituciones, las asociaciones o los comités de ayuda que lo hicieron posible, así como las lagunas y las limitaciones del Derecho Internacional Humanitario, con importantes consecuencias para la vida humana durante un conflicto de envergadura, como la Segunda Guerra Mundial.

PALABRAS CLAVE: Ayuda humanitaria; Segunda Guerra Mundial; Población civil; Francia; CMS; CICR.

Copyright: ( 2019 CSIC. This is an open-access article distributed under the terms of the Creative Commons Attribution 4.0 International (CC BY 4.0) License. 


\section{INTRODUCTION}

En fait, dès les premiers jours de la guerre, la chasse au civil de l'ennemi, après le sauve- qui-peut général, a été tragique. Inutile de dire que ce furent les moins agiles, -parce queles plus inoffensifs, qui se sont vus arrêtés sans en comprendre le motif, sans avoir eu le temps ni l'autorisation d'emporter leurs effets, sans ressources aussi le plus souvent, assimilés d'une heure à l'autre à des criminels, conduits dans des camps de concentration ou dans des dépôts plus ou moins improvisés, souvent moins qu'improvisés, absolument insuffisants. Là, hommes, femmes, enfants, malades, gens de toutes conditions, entassés dans une promiscuité et un inconfort parfois pitoyables, ont vu ce provisoire se perpétuèrent l'indifférence, quand ce n'était pas la haine et les menaces, leur être largement prodiguées. C'est bien un des chapitres les plus douloureux de la guerre que le sort fait au civil, au non combattant, tombé au pouvoir de l'adversaire. ${ }^{1}$

Throughout the 20th century, the civilian population was the most defenceless victim of armed conflict and the one that suffered the most as a result of armed violence. The two world wars symbolized total war by land, sea and air with rapid modernization of combat techniques never previously put into practice. Those wars were characterized by total mobilization, both on the front and in the rear-guard where the civilian population had to place itself at the service of the war effort. The year 1914 marked the end of traditional wars in which only soldiers participated in the hostilities and the civilian population was far from the combat zone. The outbreak of the two world wars was accompanied by large scale mobilization in which the civilian population endured the harshness of the conflicts and the hardships arising from supplying the front: bombings, famine, rationing, malnutrition, diseases, epidemics, mutilation, economic blockade and counter-blockade, etc. The duration of both wars and the prioritisation of all resources for the war needs also translated into millions of civilians killed, wounded, maimed and missing.

Those wars and the interwar period characterized by contexts of violence such as civil wars, revolutions, insurrections, coups d'état, etc., represented new challenges for humanitarian organizations and demonstrated the risks that every civilian population had to face, defenceless in both legislative and humanitarian terms. Those wars and the inter-war period showed, according to Jessica Reinisch, that "war in the twentieth century became more and more a civilian experience. 2 " They also represented new challenges for humanitarian organizations, which had to focus on new categories of non-combatant victims, and demonstrated the risks faced by all civilian populations, unprotected in legislative and humanitarian terms. The reality of war and the experience on the ground inspired many humanitarian organizations of the time to diversify their spectrum of humanitarian aid, beyond the categories of the wounded, sick and prisoners of war. Thus, this article aims to contribute to the knowledge of a part of the humanitarian aid deployed during the Second World War by one of these organizations, the Joint
Relief Commission of the International Red Cross (JRC), founded with the exclusive purpose of protecting and aiding the most vulnerable European civilian population. This study sheds light on the humanitarian aid provided by the JRC in Europe and particularly in France during the Second World War, on the basis of an analysis of international treaties, conventions and projects developed since 1863 until the signing of the Fourth Geneva Convention of 1949 in order to protect the civilian population and the different categories of civilian victims of the war.

The aim of this second section, based on documentary and graphic material from the International Committee of the Red Cross (ICRC) archives, reports and institutional studies or those conducted by the CICR, hagiographic texts and scientific research, is an investigation of the aid and practices of ICRC and CMS humanitarian intervention. Analysis thus focuses on the most practical facet of humanitarian aid understood as an activity intended to relieve suffering, save lives, avoid damage and improve the situation of the vulnerable population ${ }^{3}$ via the provision of food, medicine, clothing, pharmaceutical and healthcare products, building materials, etc. In addition to studies and stimulating and useful approaches to humanitarianism and international organizations stemming from the fields of Political Science ${ }^{4}$ and International Relations ${ }^{5}$, the text seeks answers to questions like: how was that humanitarian aid possible?, of what did it consist?, how did it reach its destinees?, who were the recipients?, who funded that aid?, or what was its contribution to supplying and saving the civilian population in France?

\section{THE PROTECTION OF THE CIVILIAN POPULATION BEFORE THE SECOND WORLD WAR}

When the Second World War began, the civilian population was not protected by any international convention. In the words of the Swiss journalist Jean Pictet, regarded "as the father of the 1949 Geneva Conventions", this loophole was due to the fact that up until the beginning of the $20^{\text {th }}$ century, "le droit de la guerre était dominé par le principe que les opérations militaires doivent être limitées aux forces armées et que la population civile jouit d'une complète immunité7"'. However, the start and the evolution of the Great War completely changed this traditional view, given that the warring parties made no distinction between combatants and non-combatants, with the civilian population being the most defenceless victim of the conflict. Another major innovation of the First World War, in addition to the aspect noted above, was that of civilian prisoners. As Romain Rolland points out in the article "Inter Arma Caritas" published in 1914,

Jusque-là, il n'avait été question, dans les guerres précédentes, que de quelques otages arrêtés, çà et là, pour garantir l'exécution d'un engagement pris par une ville conquise. Mais jamais on n'avait entendu parler de populations entières razziées, emmenées en captivité, à l'instar des conquêtes antiques, comme l'usage en été 
remis en vigueur, depuis le début de cette guerre. Le fait n'étant pas prévu, rien n'a été fait pour régulariser leur situation, dans le droit de la guerre (si l'on ose associer ces deux mots). Et comme il était malaisé d'y procéder, au milieu du combat, il a paru plus simple de les ignorer. Ils sont comme s'ils n'existaient pas. Ils existent pourtant, ils existent par milliers. ${ }^{8}$

Based on the Red Cross's own humanitarian principle of international mutual assistance, the ICRC and other philanthropic organizations developed a series of relief activities specifically for the civilian population, mainly for children, women, the sick and the elderly, during both the conflict and the inter-war period. In the role of double victims of the war and the absence of an international convention to protect them, civilians were subjected to a series of measures previously unknown. The activity of the Civil Section of the International Prisoners-of-War Agency (IPWA), another innovative institution of the moment, set up in August 1914 under the auspices of the ICRC, highlighted the existence of civilian internees in enemy countries, of civilians detained in the territories invaded by enemy armies, of civilian refugees in allied countries, neutral or in free territories in their own homeland. Therefore, the First World War introduced new forms of reprisals and different categories of victims beyond hostages, such as civilian internees, deportees, refugees and political detainees. ${ }^{9}$

In 1914, when the War began, the protection of the population was contemplated in the Regulations concerning the Laws and Customs of War, annex to The Hague Convention of 1907, mainly in articles 25, 26, 27 and 28 concerning the bombings of cities, buildings and small villages. Article 50 stated that "no general penalty, pecuniary or otherwise, shall be inflicted upon the population on account of the acts of individuals for which they cannot be regarded as jointly and severally responsible. ${ }^{10 "}$ In fact, prior to 1907 , the population, persons, individuals and inhabitants were objects of some treaties, conventions, declarations or instructions on the road towards the codification of the laws and customs of war. In this sense, the so-called "Lieber Instructions" of 1863, which did not have the effect of a treaty and were aimed at the Northern States that were fighting in the American Civil War, they represented the first step in the codification of International Humanitarian Law ${ }^{11}$, since they exerted a considerable influence on the adoption by other States of similar regulations. Articles 22 and 23 of the "Lieber Code" lay particular emphasis upon citizens, stating that "the unarmed citizen is to be spared in person, property, and honour as much as the exigencies of war will admit" and that "private citizens are no longer murdered, enslaved, or carried off to distant parts. ${ }^{12}$ "

A series of conventions, declarations and resolutions preceded the "Lieber Code". 1864 saw the adoption of the First Geneva Convention for the Amelioration of the Condition of the Wounded in Armies in the Field, article five of which provides that "the inhabitants of the country who bring help to the wounded shall be respected and shall remain free ${ }^{13}$ " on the basis of principles of humanity and neutrality. Four years later, the Declaration of Saint Petersburg was proclaimed, in which the contracting parties agreed to ban the use of certain weapons in war and formulated principles such as:

That the progress of civilization should have the effect of alleviating as much as possible the calamities of war; That the only legitimate object which States should endeavour to accomplish during war is to weaken the military forces of the enemy;

That for this purpose it is sufficient to disable the greatest possible number of men;

That this object would be exceeded by the employment of arms which uselessly aggravate the sufferings of disabled men, or render their death inevitable;

That the employment of such arms would, therefore, be contrary to the laws of humanity. ${ }^{14}$

The Declaration of Saint Petersburg promoted other projects and laws of war and the adoption of similar declarations in the two Hague Peace Conferences of 1899 and 1907. In 1874 the Project of an International Declaration concerning the Laws and Customs of War, was drafted in Brussels with a total of 56 articles, of which the most relevant for the subject at hand was number 38 : "Family honour and rights, and the lives and property of persons, as well as their religious convictions and their practice, must be respected. Private property cannot be confiscated. ${ }^{15 "}$ "The "Brussels Project" served as a model for the Oxford Manual adopted by the Institute of International Law in Oxford, in 1880. The Oxford Manual, divided into five parts, contemplated through the 86 articles, general principles, hostilities, the situation of prisoners of war, persons interned in a neutral territory and criminal sanctions. One of the major innovations of the Manual was the distinction between "armed forces" and "ressortissants", non-admission of acts of violence, save between the armed forces of warring States, and a ban on mistreatment of harmless populations. ${ }^{16}$

All such activity in the field of International Humanitarian Law established the bases for the adoption of The Hague Conventions of 1899 and 1907, whose texts and regulations are slightly different. Unlike the aforementioned Convention of 1907, in the Convention (II) with Respect to the laws and Customs of War and Land of 1899 , the contracting parties agreed that in certain cases not included its Regulations "populations and belligerents remain under the protection and empire of the principles of international law, as they result from the usages established between civilized nations, from the laws of humanity, and the requirements of the public conscience. ${ }^{17}$ " In addition, in Section III entitled "On military authority over hostile territory" the situation of the population was addressed in three articles, the last one being a summary of article 38 of the "Brussels Project":

Art. 44. Any compulsion of the population of occupied territory to take part in military operations against its own country is prohibited. 
Art. 45. Any pressure on the population of occupied territory to take the oath to the hostile Power is prohibited. Art. 46. Family honours and rights, individual lives and private property, as well as religious convictions and liberty, must be respected. Private property cannot be confiscated. $^{18}$

As was stated in 1946 during the Nüremberg International Military Tribunal, those Conventions represented at the time an important advance in the field of International Law and were regarded as embodying the rules of customary international law. ${ }^{19}$ In spite of this, the existing gaps in the protection of the civilian population became evident as the Great War unfolded, given that contrary to the provisions made for prisoners of war in The Hague Conventions of 1899 and 1907 and the annex Regulation of 1907, it did not contemplate the possibility of civilians receiving relief; nor did it address the issue of the interment of the citizens of a warring State in the enemy territory. ${ }^{20}$ Therefore, the experience of the first global armed conflict triggered the development of a series of Conferences and projects during the interwar period in order to respond to the humanitarian problems detected.

From 1921 to 1938 seven International Red Cross Conferences were held, as well as numerous International Conferences of experts, which attempted to further develop into and establish the bases for an international convention for the protection of the civilian population during war. For that purpose, at the $10^{\text {th }}$ International Conference of the Red Cross in 1921 a project was submitted on the moderation of the economic blockade for sick people and children from warring countries and occupied territories. An invitation was also sent to governments to agree on additional measures to the IV Hague Convention of 1907, in accordance with the following proposals:

1. Prohibition absolue de l'usage des gaz comme moyen de combat, de quelque manière qu'ils soient employés, en nuages, par projectiles ou autrement.

2. Limitation de la guerre aérienne à des buts militaires, en sorte que la population civile soit préservée autant que possible des effets de ce nouveau moyen de combat et que des destructions inutiles soient évitées.

3. Application stricte de l'article 25 du Règlement de la Haye, interdisant le bombardement de toutes les localités non défendues, et définition de ce qui est entendu par « localités non défendues », en sorte que cette interdiction ne soit pas trop facilement éludée. ${ }^{21}$

Similar views were expressed by experts convened at the Commission of Jurists at Hague in late 1922 and early 1923, whose General Report prohibited aerial bombing designed to terrorize the civilian population or to destroy and damage private property, or attacks on cities, towns and buildings located outside areas of military operation. ${ }^{22}$ That same year also saw the $11^{\text {th }}$ International Con- ference of the Red Cross, perhaps one of the most emblematic of the twenties as it presented an innovative project of Convention internationale relative aux civils, internés, déportés, évacués et refugiés drafted by Dr. Frédéric Ferrière, heart and soul of the Civil Section of the IPWA, defender and promoter of relief activities for the civilian population during the First World War and in the post-war period. ${ }^{23}$ The experience of the war itself and its consequences motivated that report, which concluded:

On a quelque peine à comprendre le motif qui a engagé les Etats en guerre à soumettre à un régime particulièrement dur des victimes, pour le plus grand nombre absolument étrangères aux événements de la guerre : femmes, vieillards, enfants, infirmes, etc. Ce serait à croire que les gouvernements et les peuples, conscients de l'absence de toute convention internationale visant à la protection des civils retenus captifs, ont cédé à la tentation malsaine de faire peser sur ce troupeau sans étiquette protectrice, sur ces victimes sans défense, sur ce matériel humain, trop commode pour l'exercice des représailles toute leur haine à l'égard de la nation ennemie. ${ }^{24}$

Ferrière's project included seven specific proposals that condemned, restricted and prohibited reprisals against civilians-particularly women, children, the elderly and the sick-, mass deportations and displacement of the population. In addition, they stipulated that populations in the occupied territories had the right to exchange correspondence, to receive relief and visits by neutral commissions. ${ }^{25}$ The results of the Conference materialized in an appeal to the governments of the time to reach a common agreement and eliminate practices against humanity. As on previous occasions, the activities of the International Conferences of the Red Cross of 1925, 1928 and 1930 had in common the protection of non-combatants in enemy territory, the appeal to the signatories of the Geneva Convention to respect the Geneva Protocol of 1925 regarding the ban on the use in war of Asphyxiating, Poisonous or Other Gases, or proposals to relax the economic blockade for sick people and children from warring countries or occupied territories. ${ }^{26}$

The decade of the thirties witnessed the adoption of a new project called Draft International Convention concerning the condition and the protection of Civilians of enemy nationality in the territory of the a belligerent or in a territory occupied by it, known as the Tokyo Draft, precisely as it was adopted in the Japanese city at the $15^{\text {th }}$ International Conference of the Red Cross of $1934 .{ }^{27}$ This draft Convention prepared by ICRC, which was to be discussed at the diplomatic conference scheduled for 1940, included four parts: one that defined the status of enemy civilians; the second on enemy civilians in the territory of a belligerent; the third, concerning enemy civilians in the territory occupied by a belligerent; and the fourth, on the modalities of implementation of the convention. ${ }^{28}$

The outbreak of a new war in Europe obviously prevented the holding of that diplomatic conference. What is more, it thwarted a possible implementation of the resolutions of the $16^{\text {th }}$ International Conference of the Red 
Cross of 1938, a year marked by tensions, territorial annexations and ongoing wars such as those in Spain and China. The $16^{\text {th }}$ Conference reiterated the calls for the protection of the civilian population in the following terms:

Les 54 Sociétés nationales de la Croix-Rouge [...] en attendant les résultats de leurs efforts pour assurer des mesures générales pour la protection de la population civile, s'adressent au nom de l'humanité aux autorités compétentes de tous les pays afin d'empêcher ou de restreindre les bombardements aériens de façon que soit sauvegardée la vie des femmes, enfants et vieillards sans défense. Les Sociétés adressent un appel pressant à ces autorités pour que, dans tous les lieux où la vie des civils peut être mise en danger par des opérations militaires, il soit pourvu à l'évacuation des femmes et des enfants dans des zones de sécurité sous la protection de la Croix-Rouge. ${ }^{29}$

The last effort recorded during the interwar period, as well as the last call in that domain, was the Draft for the Protection of Civilian Populations Against New Engines of War prepared by the International Law Association and approved during the Fortieth Conference of the Association in Amsterdam $1938 .{ }^{30}$ Consequently, in September 1939 , the protection of the victims of war was only reinforced by the two Geneva Conventions of 1929: the Agreement for the improvement of the conditions of the wounded and sick in armies in the field and the Agreement relative to the treatment of prisoners of war. ${ }^{31}$ As André Durand notes, perhaps the most opportune time for the signing of agreements relative to civilian protection would have been between 1925 and 1929, when the two major post-war humanitarian conventions were implemented, given that the subsequent epoch was marked by new conflicts, global crisis, mistrust and spirit of protest. ${ }^{32}$

Although the need for new laws to assist and protect the civilian population became evident during the Great War, this absence continued during World War II, with devastating consequences for all civilian victims of the conflict. The ICRC had failed in its humanitarian action with regard to many of the civilians in the occupied territories, especially those deported to the extermination camps. And, during the post-war period new appeals were launched, such as the following:

The Geneva Convention gives guarantees to the wounded and sick of the armed forces- just as to their adversaries- that their lives will be protected and that they will have the right to proper care; the Convention on the treatment of prisoners of war watches over the physical and moral situation of those in captivity. The terms of these instruments declare the absolute inviolability of an enemy who is no longer fit for combat and give recognition to the dignity of the human personality. Protection of the civil population must rest on these same principles. The same applies to the endeavours made by the Red Cross to bring relief supplies of all kinds- foodstuffs, clothing and indispensable medicaments- to women, children and old people in occupied territories.
Safeguarding of children is the last line which the Red Cross must defend, if war is not to mean utter destruction of mankind. ${ }^{33}$

In Tony Judt's words it was that great "trauma that lay behind the images of desolation and hopelessness that caught the attention of the observers in $1945 .{ }^{34}$ " Four years after the end of the war, forty-eight States reviewed the Geneva Conventions of 1864, 1906 and 1929 and adopted the four Geneva Conventions: Geneva Convention for the Amelioration of the Condition of the Wounded and Sick in Armed Forces in the Field; Geneva Convention for the Amelioration of the Condition of Wounded, Sick and Shipwrecked Members of Armed Forces at Sea; Geneva Convention relative to the Treatment of Prisoners of War; and Geneva Convention for the Protection of Civilian Persons in Time of War. ${ }^{35}$ The latter was a completely new Convention, marking a significant development with regard to the protection of civilians, victims of war.

\section{THE SECOND WORLD WAR AND THE JOINT RELIEF COMMISSION OF THE INTERNATIONAL RED CROSS}

A few months after the beginning of hostilities in Europe, in July 1939, the ICRC President, Max Huber, in his speech before the Swiss Red Cross in Zurich, identified the organisation's main priorities, whilst predicting an extension of the Committee's sphere of activity:

\begin{abstract}
Le premier devoir, l'impérieuse obligation de la CroixRouge, est de venir en aide aux hommes qui souffrent, sans avoir à prononcer des jugements moraux, ni des sentences juridiques. La Convention de Genève protège les soldats blessés ou malades des armées en campagne; mais la guerre fait encore d'autres victimes. Songeons aux prisonniers en tout genre, aux grands blessés, aux incurables, aux malades qu'il faut hospitaliser dans un meilleur climat; pensons aux populations évacuées en pays ennemi, aux étrangers qu'en temps de guerre on tient pour des adversaires, pensons à toutes ces familles dispersées dont les membres sont sans nouvelles les uns des autres. ${ }^{36}$
\end{abstract}

The outbreak of the Second World War, the start and the development of the hostilities in Europe and the food and health crises in many of the countries affected by the conflict once again had serious repercussions for the civilian population. In this context, the lessons and consequences of the Great War were insufficient for the progress required in questions of civilian protection and history would repeat itself but on a far larger scale. As had occurred during the First World War, and as addressed in the study by Tammy M. Proctor, the war militarized civilian populations, mobilized civilians and resources for the war effort and created new kinds of victims. Ultimately, the new era of large-scale war turned civilians into part of the war and direct victims of the violence. ${ }^{37}$ Similarly, these wars completely blurred the border between soldiers and civilians. ${ }^{38}$ As Nicole Dombroski Risser notes in her research into the French civilian 
population and its survival during the Nazi invasion and occupation, "the speed of the German assault destabilized any clear distinction between battle zone and home front, erasing any imagined "safe space" to which the French could reliably move civilians. ${ }^{39}$ "

From the perspective of the history of humanitarian aid, the Second World War may be interpreted as a prolongation of the experience acquired during the Great War. ${ }^{40}$ From the first months of the conflict, civilians represented an unprecedented and large-scale humanitarian problem. Their situation attracted the attention of numerous humanitarian organizations of the time. Among them were some of the best known for their doctrine, the assistance they provided during the Great War and post-war in Europe and their concern, expressed in conferences or materialized in draft conventions, for the victims of war, particularly the most vulnerable elements of the civilian populations, namely babies, children, women and the elderly. This was the International Committee of the Red Cross, a humanitarian organization which during world wars, revolutions and civil unrest broadened its field of action - initially restricted to the war wounded- to include other categories such as prisoners of war, political detainees, victims of famines and epidemics and civilian populations. ${ }^{41}$ ICRR and its sphere of activity. ${ }^{42}$ An institution with its roots in Swiss aristocratic philanthropy, with a steering committee formed by twenty-five members, Protestant Genevan patricians, the main objectives of the ICRR when war broke out were to coordinate Red Cross activities for refugees and develop a prisoners of war agency, similar to that of the First World War. ${ }^{43}$ In line with Huber's announcement in 1939 and another declaration of intentions in 1940 aimed at more effective action in support of war victims, the ICRC and the League of the Red Cross Societies, Federation of all the National Societies of the Red Cross, which decided to collaborate in the field of protection and international relief in wartime for the civilian population, especially children and women. To this end, both institutions created a non-profit association called the Joint Relief Commission (JRC), formed officially on the $23^{\text {rd }}$ of July 1941 , even though it had actually been created in the fall of $1940 .{ }^{44}$ The JRC foundation, joint body of the ICRC and of the League, was based upon the core principles of the Red Cross, namely humanity, impartiality, neutrality, independence, volunteering, unity and universality ${ }^{45}$ and in accordance with the statutes of the International Red Cross, adopted at the $13^{\text {th }}$ International Conference of the Red Cross held at the Hague, in 1928, Article 9 of which stipulated:

The International Committee of the Red Cross and the League of Red Cross Societies shall cooperate in matters touching upon the activities of both, and especially in regard to the endeavours of relief organizations in the event of national or international calamities. ${ }^{46}$

At the organizational level, the work of the JRC was carried out under the supervision of a Committee composed of two members of the ICRC, two members of the
League and a managing director who did not belong to either of the two Red Cross institutions. Given the scale of the JRC' objectives and political, economic, technical and social circumstances of those years, the Commission benefitted from the cooperation of people specialized in commercial, legal and financial fields who performed their activity in the different services of the association: the central secretariat, the food and clothing service, the pharmaceutical service, the transport service, the accounting and the statistics services. ${ }^{47}$

From its establishment in 1940 to its dissolution in 1946, the JRC became a technical tool for seeking, negotiating, transporting and distributing humanitarian aid in Europe for the civilian population. As the agency did not have its own financial funds, its labour relied entirely on the donations received, whether economic or in kind, for a specific country or for a certain segment of the population. ${ }^{48} \mathrm{In}$ this way, the humanitarian aid acquired and distributed in Europe was possible thanks to private donations, donations by pharmaceutical manufacturers from Bâle, tobacco manufacturers, or thanks to the collections organized in Switzerland. It is worth mentioning contributions made to the relief of the civilian population in various European thanks to the funds made available to JRC by aid committees, religious, ethnic, philanthropic or charitable associations such as: the Union OSE (EEuvre de Secours aux Enfants), the Union internationale de secours aux enfants, the Conseil œcuménique des Eglises, the Fonds européen de secours aux étudiants, the Fédération des Communautés israélites suisses, the Aide aux Emigrés, the Schweizerische Aerzteverein, the Secours d'Hiver belge, the Secours national français, the Comité de Coordination pour le Ravitaillement de la Belgique, the Greek War Relief Association, the Royal Committee of Yugoslavia, the Hungarian Relief Committee, the Don Suisse pour les victimes de la guerre, the American Joint Distribution Committee, the Quakers, the Apostolic Nunciature of Bern, Caritas, Evangelisches Hilfswerk. Along with these national and international organizations there were also governments such as the Irish, Swiss, Greek, Yugoslavian, Norwegian, Dutch and Romanian that assisted with European supplies and those for their respective populations. ${ }^{49}$

Similarly, the development of the JRC's activity was due to the tools provided by its founding members., As David P. Forsythe ${ }^{50}$ reasons, the ICRC, the oldest humanitarian organization, had a prestigious reputation and diplomatic contacts, based on humanitarian operations deployed during former intra- and inter-state armed conflicts, or the interwar period. During the Second World War, the committee was able to operate in many of the belligerent countries with the agreement of the corresponding governments, thanks also to delegations established in different European cities, to the work of the delegates - observers and informers-, who acted in the field gathering information in situ, thus preparing reports on the most pressing needs in a specific territory and strengthening the ties of collaboration with other agencies working in the same zone. ${ }^{51}$ For its part, the policy and mission of the League of the Red Cross Societies consisted in establishing and cementing links 
with National Societies from all over the world, which facilitated the collection in kind of economic and relief funds.

Between 1940 and 1946, JRC humanitarian policy was conditioned by the development of the war, the economic blockade and counter-blockade applied by the belligerent powers, a situation that required negotiations both with Germany and with the allies in order to import overseas products. In a letter dated 11 January 1941 to the ICRC, the Ministry of Foreign Affairs of the Reich agreed in principle that the humanitarian aid for the civilian population could be sent to territories occupied by German troops under the following conditions: the action should be collective and not for an individual recipient; the German Red Cross would be responsible for organizing and controlling the distribution of relief supplies; the local organizations would be in charge of the distribution; the representatives of the donors would verify the distribution made in the occupied territories; and Germany would undertake not to make deductions for the benefit of German troops or officials. The response of a non-democratic country like Germany would contrast with the position adopted by a country with a long democratic tradition like Great Britain. Archive materials and recent studies on the question indicate the opposition of Britain and the allies in general to the lifting of the blockade under the argument that the strict application of the blockade would help to defeat the enemy and lead to a faster ending of hostilities. For Churchill, responsibility for supplying and feeding civilian populations in those countries invaded by the Third Reich lay with the occupying forces, which in turn benefitted from these countries' resources, many of which were requisitioned. ${ }^{52}$ In Ronald Zweig's words:

The obstacles to be overcome in organizing food relief characterized all rescue and relief projects. Despite the small quantities of food, clothing, medicines, and money involved, the blockade policy of the Allies inhibited any attempts to send aid. The policy was liberalized when public opinion in the United States became increasingly critical of the blockade's effect on civilian populations in the occupied countries. ${ }^{53}$

Consequently, from the summer of 1940 onwards, the blockade was applied to the free French zone, hindering the aid efforts by different international organizations in favour of refugees in the south of France. On an exceptional basis, during the war the blockade would be lifted, allowing for the passage of goods, especially for prisoners of war and for those civilians most affected, as was the case of the Greek population or of the internees in the South of France. ${ }^{54}$

The JRC and other humanitarian organizations of the time not only had to face the economic blockade but also problems such as the availability of goods, the possibility and authorization of transport and transit through Europe, the funds available and their allocation, depending on the most pressing demands or the wishes of donors. ${ }^{55}$ Despite various difficulties and the initial lack of funds, between 1941 and 1946 the JRC obtained, transported and distributed to Europe 165,256,256 tonnes of goods, totalling $314,251,522$ Swiss francs. The statistical analysis of the annul shipments shows their evolution: in 1941, 2,538,801 tonnes of humanitarian aid were sent; in 1942, 28,035,470 tonnes; in 1943, 39,474,878 tonnes; in $1944,8,201,803$ tonnes; in 1945, 15,266,058 tonnes; and in $1946,71,738,246$ tonnes. ${ }^{56}$

Although the JRC was a relatively pioneering organization in its exclusive foundational and operational purpose of assisting the civilian population, its activity and shipments in Europe were quite modest, especially when compared to the amount and value of the goods destined for prisoners of war via the Relief Division of the ICRC. By way of example, between 1941 and 1943, 123,700 tonnes of humanitarian aid was dispatched, totalling 1,800 million Swiss francs. In 1943, in fact, civilian populations of Europe received only a $28.9 \%$ of the volume and $8.8 \%$ of the total value of the shipments sent to prisoners of war in Europe. If the total volume and value of the goods purchased by JRC are compared with those of the Relief Division for the prisoners of war, it turns out that the civilian populations received only $10.6 \%$ of the volume and $3.9 \%$ of the value of the aid for prisoner of war. ${ }^{57}$ This comparative approach clearly indicates the consequences of the absence of treaties to help and protect the civilian population, far greater in number than the prisoners of war during the Second World War.

The European population that benefited from JRC relief in food, clothing, medicines, pharmaceutical products, as well as intellectual and moral support, came from sixteen countries. During the war, Belgium, France, the Netherlands, Norway, Finland, Greece, Yugoslavia, Poland and to a lesser extent Italy and the Baltic countries, were among the main beneficiaries. From 1945 onwards, the humanitarian map of the JRC changed, since most of the aid went to the countries of Central and Eastern Europe, ravaged by the war, such as Romania, Bulgaria, Poland, Yugoslavia, Albania, Germany and Austria. Even so, thanks to the donations received until its dissolution in 1946, the JRC continued to allocate a part of the aid to Western countries, including France. ${ }^{58}$

\section{JRC HUMANITARIAN AID IN FRANCE}

France was one of the countries that benefitted most from the humanitarian aid distributed by JRC, as from the moment war broke out in Europe, the situation of the civilian population attracted the attention of the ICRC, the League and various humanitarian organizations. According to ICRC and JRC reports, the economic and nutritional situation in the country was critical. A range of factors contributed to this, such as the blockade, land and maritime transportation difficulties, the scarcity of resources because of the war, rationing, internment of French prisoners in Germany, the occupation of large part of the country and the deductions made by the German army, massive destruction suffered by different regions, cities or villages. ${ }^{59}$ The situation was further aggravated due to the presence of a considerable number of foreign citizens, mainly Belgians and Dutch, who in their flight from the 
German troops sought refuge in the South of France, as did the French from the north of the country and before that thousands and thousands of Spanish Republicans during the Retreat and after the outcome of the Civil War:

Some three million French, two million Belgian, seventy thousand Luxemburg and fifty thousand Dutch refugees or evacuees are in a serious state of destitution in France. The French Red Cross appeals to sister Societies for relief of people in distress. Needs are new clothes, shoes, layettes, bedding, kitchen utensils, minor surgical instruments, dressings, non-perishable foods, collapsible huts, textiles for workshops. Please send gifts in cash or kind to the Central Committee French Red Cross Paris and through the Véron transport agent for all ports. ${ }^{60}$

Based on JRC founding principles, particularly article 2, aid measures of the commission in French territory focused on some groups of the civilian population. In the first place, children, as mentioned in one of the Commission's reports, "children are always the most exposed group in a civilian population affected by famine. ${ }^{61}$ " According to another statistical report entitled Commission mixte de secours de la Croix-Rouge Internationale. Vivres et Vêtements. Envois en France 1941-1942-1943, the other target groups for JRC aid were pregnant and nursing women, the sick, the homeless, the elderly, refugees and civilian internees. ${ }^{62}$

It was in May 1940 when relief for the French population started, and it continued intermittently until just after the war, with the dissolution of the JRC in 1946. The typology of the humanitarian aid delivered during that temporary lapse was the same for the rest of the European countries and it could be classified as follows: food, particularly dairy products such as milk powder and condensed milk for children and women, clothing, textiles, medicines and other healthcare and pharmaceutical products, barracks, material and tools for construction. To all these was added moral assistance, such as the collections made in Switzerland that allowed for the shipping of toys, since

\footnotetext{
Au cours du présent conflit, des millions d'enfants ont été les témoins et les victimes d'indescriptibles tragédies et d'une longue misère ; des millions d'enfants aux nerfs ébranlés, qui savent ce que sont la faim et le froid, mais qui n'ont jamais connu, ou qui ne connaissent plus, ce qu'est une vie normale, et moins encore ce qu'est une enfance insouciante, avec les joies et les plaisirs qu'elle comporte. ${ }^{63}$
}

Along with the toys, glasses, dentures and orthopaedic devices were the object of other collections made in the Swiss territory. Humanitarian, food, material, moral and intellectual aid had different intermediate recipients in the form of applicants or donors or was delivered directly to recipients by a JRC or ICRC representative. Among the donors for France were French institutions and humanitarian organizations that operated in certain areas or localities that, in most cases and sometimes with the collaboration of an ICRC delegate or JRC representative, were in charge of the distribution of the humanitari- an aid for the civilian population and for refugees and civilian internees in the camps of southern France.

The national institutions, the aid committees and humanitarian organizations that through their donations or allocation of funds made it possible to supply France were: the French Red Cross (FRC), the Secours National (SN), the Swedish Red Cross, the American Red Cross, the Canadian Red Cross, the British Red Cross, the CroixRouge Suisse-Secours aux Enfants, the CEuvre d'entr'aide ouvrière, the Quakers, the International Relief Committee, the American Relief for France, the Unitarian Service Committee, the Conseil œcuménique des Eglises, Caritas, the Colis Suisse, the Union Internationale de Secours aux Enfants, the First Church of Christ, Scientist, the American Friends Service Committee, the Service Civil International, the Don Suisse pour les victimes de la guerre. ${ }^{64}$

Within these, the FRC and the SN played a fundamental role. According to the emblematic study by Jean-Pierre Le Crom, the CRF humanitarian aid, part of which was acquired through the JRC, was destined for refugees, the wounded, air raid victims, nursing women and the protection of children with the creation kindergartens and infant schools. In spite of its dependence upon SN subsidies and loans, its control by and subordination to that institution, which affected its neutrality, and the interventionism of the occupying authorities, the FRC developed humanitarian activity appreciated by both the population and the Germans, who preferred it to be the sole interlocutor in this area. ${ }^{65}$ Meanwhile, the SN, an institution instrumentalized by Vichy power and associated with the image of the French Head of State, focused its aid policies on combatting hunger, and on civilian war victims, prisoners' wives, children, refugees, the wounded and camp inmates. ${ }^{66}$

The most significant contribution was probably that of the Croix Rouge Suisse-Secours aux enfants, which from 1942 onwards acquired around 2,071 tonnes of goods in Switzerland for different European countries, including maternity wards, nurseries, school camps and canteens in France. From 1942 to 1944, the JRC played an intermediary role since it ensured the management of export authorizations. It also organized dispatches on behalf of the Croix-Rouge Suisse-Secours aux enfants. ${ }^{67}$ Another significant contribution in the fight against the famine and hardship resulting from the war in Europe was that of Don Suisse pour les victims de la guerre. Between its founding in 1944 and 1946, the Don Suisse brought relief to seventeen European countries with approximately 60,000 tonnes of food, clothing, medicines, surgical instruments, furniture, barracks, wood, material and tools for construction. Like the Croix-Rouge Suisse-Secours aux enfants, the Don Suisse worked closely with the JRC, whose members gathered information about the most needy areas and population. On the basis of the reports provided, the JRC organized the dispatch and transport of the humanitarian aid on behalf of Don Suisse, which in that period assisted the French population with around 10,000 tonnes of humanitarian aid..$^{68}$

Together with the French children and women, the civilian internees in the camps in the south of France re- 
ceived very modest humanitarian aid from or via the JRC, on the basis of the orders issued by other humanitarian organizations. The ICRC's humanitarian aid to the southern French camps began in the summer of 1940, when a first shipment left Geneva. Between July and August 1940, some 3,000 boxes of condensed milk, $12,000 \mathrm{~kg}$ of milk powder and 5,000 packages of food and clothing were received in French camps. In November 1940, following the visit of an ICRC delegate in the camps of Gurs, Vernet d'Ariège and Argelès-sur-Mer, 300 kilos of healing material, medicines and surgical instruments were distributed, as well as 265,000 French Francs, funds handed over to the ICRC by relatives or friends of the internees. ${ }^{69}$

That visit, like those made in the years to come in the camps of Rieucros, Rivesaltes, Récébedou, Noé, Le Vernet, Barcarès or Les Milles, provided a closer look at the prevailing reality and the most pressing needs of refugees of different nationalities. Also, the presence of various relief works in the camps such as the Quakers, the YMCA (Comité de coordination des associations travaillant in faveur des internés et réfugiés étrangers in France), the CIMADE (Comité inter-mouvements auprès des évacués), the Union OSE or the collaboration of others such as the Conseil œcuménique des Églises, the Fédération des Communautés israélites suisse, the Aide aux Emigrés, the Swiss section of the International Migration Service, the Schweiserische Aerztverein, favoured the distribution of that aid on the basis of the reports provided by their delegates or based on donations received with special allocation for the camps.

Between July 1941 and August 1943, JRC dispatched medicines, vitamins, pharmaceutical specialties, curing and disinfection items and drugs, all of this the result of donations from pharmaceutical companies. The material was sent directly to the camps of Argelès-sur-Mer, Barcarès, Gurs, Les Milles, Noé, Récébedou, Rieucros, Rivesaltes, Le Vernet, to various hospitals in Purpan, Dordogne, Sabart and Saint Louis, as well as to the Comité de Nîmes or Comité de Coordination pour l'assistance dans les camps. ${ }^{70}$

Another type of aid distributed in the same time period consisted of tins of sardines bought in Portugal and 41,450 cigarettes distributed among the male population of the camps of Gurs, Le Vernet, Noé, Récébedou, Rivesaltes and Les Milles. Thanks to the collaboration of the Quakers, who had collected 60 million tonnes of clothes in the USA, the JRC was in charge of the distribution of the garments in the French camps and children's colonies, following authorization by the competent authorities to distribute that relief received from overseas. According to the various reports prepared by the JRC delegate in France, 13,601 people received 51,888 garments and 220 pairs of socks. ${ }^{71}$ In parallel, the JRC distributed more than a thousand blankets, 2,140 pairs of glasses, 286 different prostheses and more than 5,000 types of teeth. ${ }^{72}$ The action of the JRC in the camps of southern France was complemented as far as possible by individual relief shipments and cash transfers made by the ICRC through the postal transit service and at the request of friends or relatives of the internees. ${ }^{73}$
Although the work of JRC in France and in other European countries was quite modest, it represented a further contribution to the joint work carried out by many charitable organizations to help the civilian population. Archival documentation, as well as the various reports and brochures of the JRC cited throughout this document, allows for a very approximate quantification of the humanitarian aid to the French population and to the civilian internees in French camps. Between 1941 and 1946, these groups received a total of 19,471,398 tonnes of goods, worth $37,775,369.25$ Swiss francs, that is to say, approximately one quarter of the total aid distributed in Europe. Therefore, over a period of five years, the JRC sent 19,212.1 tonnes of food and textiles and 189,298 tonnes of pharmaceutical products in France. ${ }^{74}$

\section{CONCLUSIONS}

According to Michael Barnett "World War II transformed the world of humanitarianism. ${ }^{75}$ " The nature of the war, massive destruction in Europe, the broadening of the categories of civilian victims and the consequent need for aid in all the countries affected saw the emergence of national and international goodwill and solidarity which in turn encouraged and favoured the humanitarian work of the Red Cross societies and humanitarian organizations. In the words of Sébastian Farré, the allied national societies, and other institutions of that ilk, became humanitarian machines that made humanitarian aid possible thanks to the creation of a humanitarian space born of a tacit or official agreement between the warring parties. ${ }^{76}$

The nature of the conflict marked their actions and led to major transformations within these organisations. The ICRC was no exception, since the dynamic of the war and its ideological character resulted in significant changes. According to Jean-Claude Favez, before hostilities broke out, the ICRC was a relatively small institution, with limited resources. By the end of the war, the ICRC had become a permanent administrative giant with hundreds of delegates, professionals and collaborators. ${ }^{77}$ Similarly, the International Committee became a sort of international post officer at the service of donors, a trust company, a mobilizer of public and private resources, an organiser of transport and of distribution models. ${ }^{78}$

The evolution of the wars and their consequences during the first half of the $20^{\text {th }}$ century involved a diversification of humanitarian aid and its recipients, even if the civilian population were not contemplated by international treaties and conventions of the time. Like other humanitarian organizations cited here, the ICRC and JRC faced obstacles, often complex in nature, such as the legal status of victims of war, the simultaneous negotiations with many of the governments of the time, the principles applied by the authorities that imposed blockades, the shortage of donations, etc.

The ICRC, a humanitarian instrument designed and shaped to seek, assist, relieve and repatriate prisoners of war, tried to extend its humanitarian action beyond that category through the JRC, based exclusively on its statutes, since there was still no IV Geneva Convention. It 
was an attempt to reinvent, diversify and evolve in step with total war, in addition to maintaining or consolidating its leadership in the humanitarian field. In spite of the effort and intentions of the Geneva organization, the JRC was unable to organize and deploy a large-scale humanitarian operation due to the aforementioned hindrances.

Moreover, the institutional policies of the ICRC, hugely influenced by the prevailing opinions within the Committee, comprised too of anti-communists, Germanophiles and anti-Semites, and in the interest of the Swiss Confederation, conditioned the actions of the institution, which advocated a policy of appeasement and silence vis-à-vis the barbaric Nazi treatment of the civilian population in the occupied territories and the murder of millions of Jews. ${ }^{79}$ In this sense, if during the Great War the ICRC benefited from its work in favour of prisoners of war, earning it a Nobel Prize in 1917, its limitations in the perception of the war, its policies, silences, omissions and errors in the protection of civilians and mass deportees during the Second World War would weigh heavily upon its image in the ensuing years.

Even so, the JRC was an innovative instrument in the era of war, for at the service of and humanitarian organizations and efforts in order to locate, manage, buy and trans- port goods and relief throughout Europe. This was possible due to collaboration by governments, the work of many humanitarian organizations, the strength and prestige of its founders, in particular the ICRC, as well as the work of the JRC delegates and staff, whose efforts made it possible to overcome the blockade and counter-blockade on occasions, locate products in the market, obtain them, transport them and dispatch them to the civilian population. The JRC and ICRC's experiences during the Second World War had a considerable impact in evidencing the urgent need for an international convention for the protection of non-combatant civilians. The activities developed by both organizations from 1939 onwards, and the obstacles they encountered in their humanitarian work, were reflected in the preparation of the Fourth Geneva Convention of 1949, which marked the beginning of the consolidation of International Humanitarian Law in the protection of the civilian population. But as Matthew Stibbe points out, even in the wake of this Convention and subsequent progress in the field, recent events in different parts of the world (Bosnia, Ruanda, Somalia, Kosovo, Chechenia, Afghanistan, Syria, Iraq, etc.) have demonstrated that civilians continue to be the targets and the main victims during wars and civil unrest. ${ }^{80}$

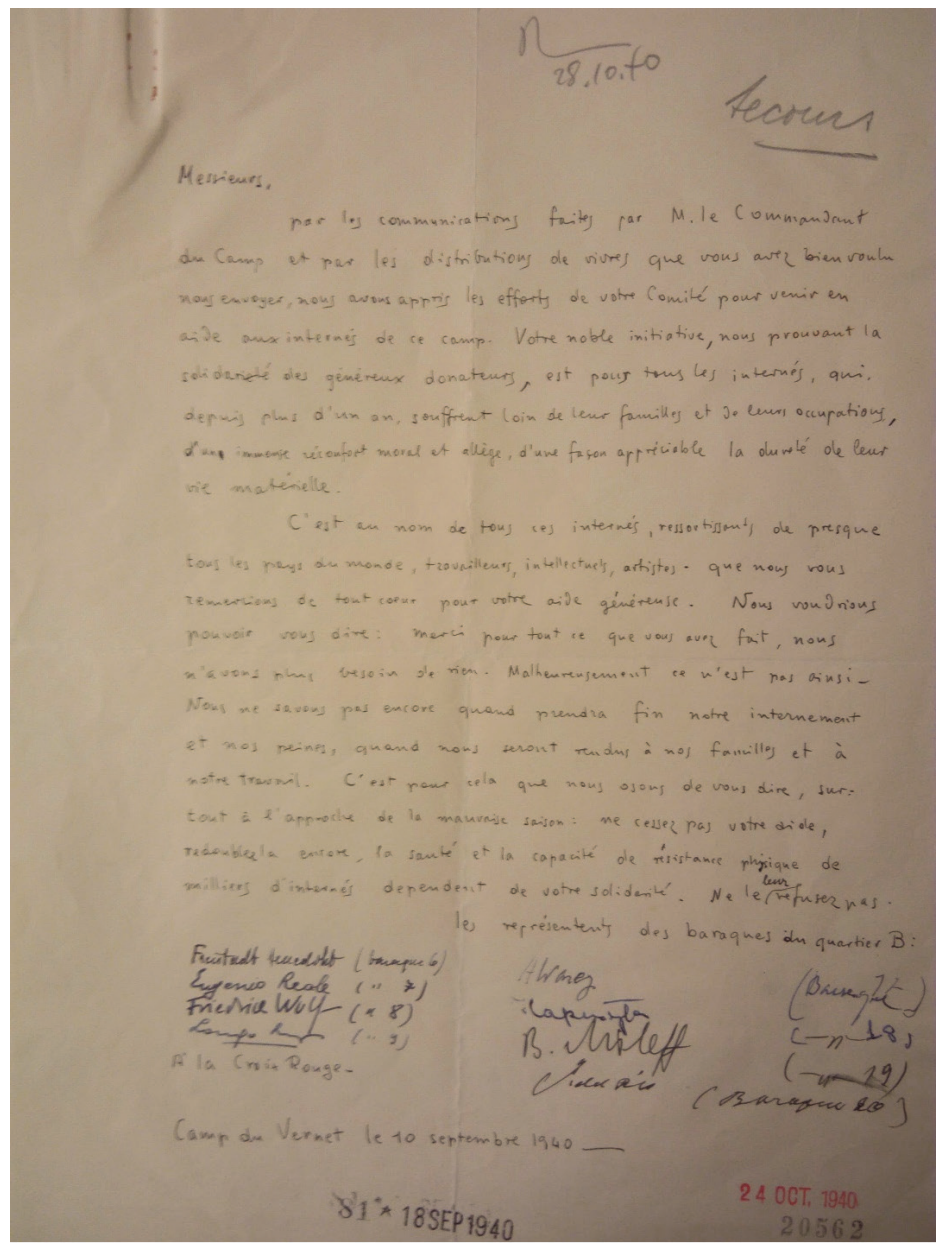

IMAGE 1. Letter of gratitude to the ICRC from a group of civilian internees in Vernet camp. Source: ACICR, O CMS D-119 
The Humanitarian Aid of the Joint Relief Commission of the International Red Cross in France to the civil population... 11

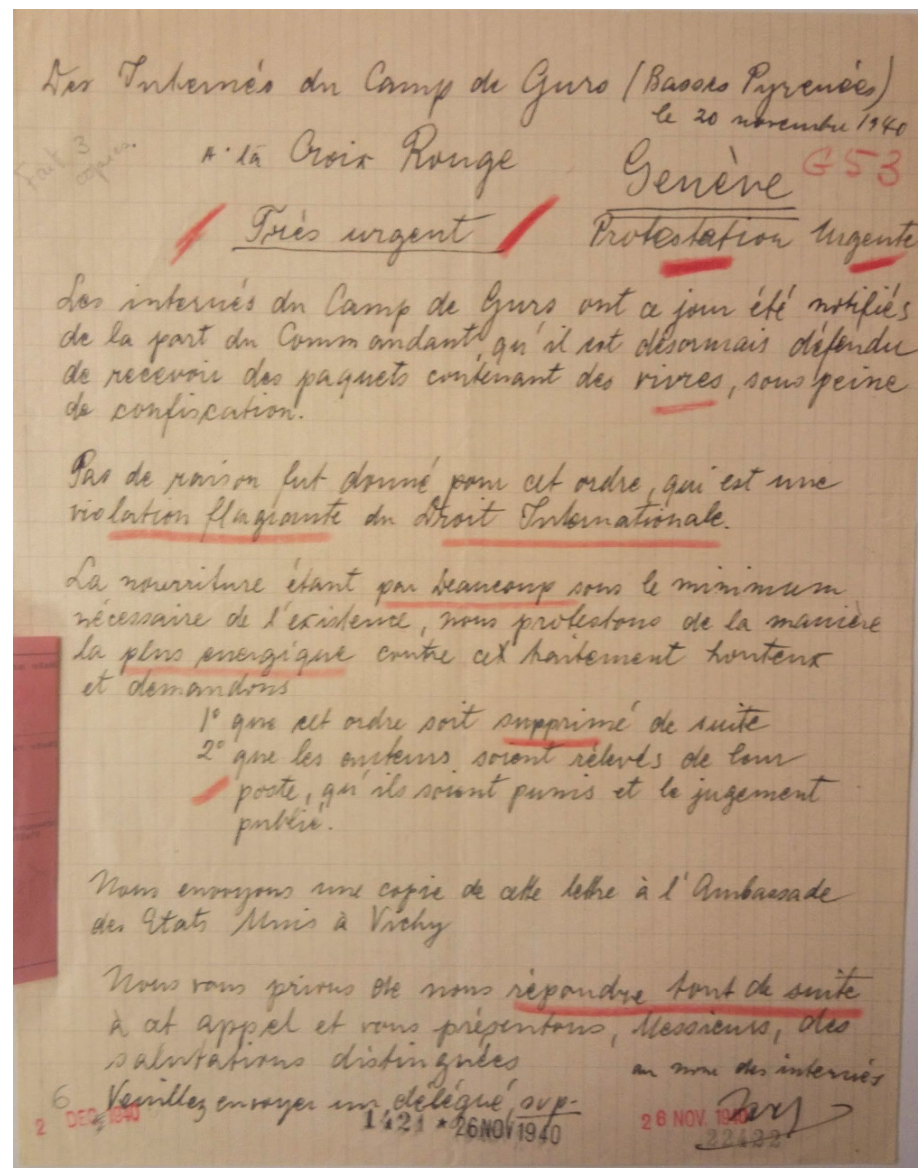

IMAGE 2. Letter to the ICRC from a group of civilian internees in Gurs camp. Source: ACICR, O CMS D-116

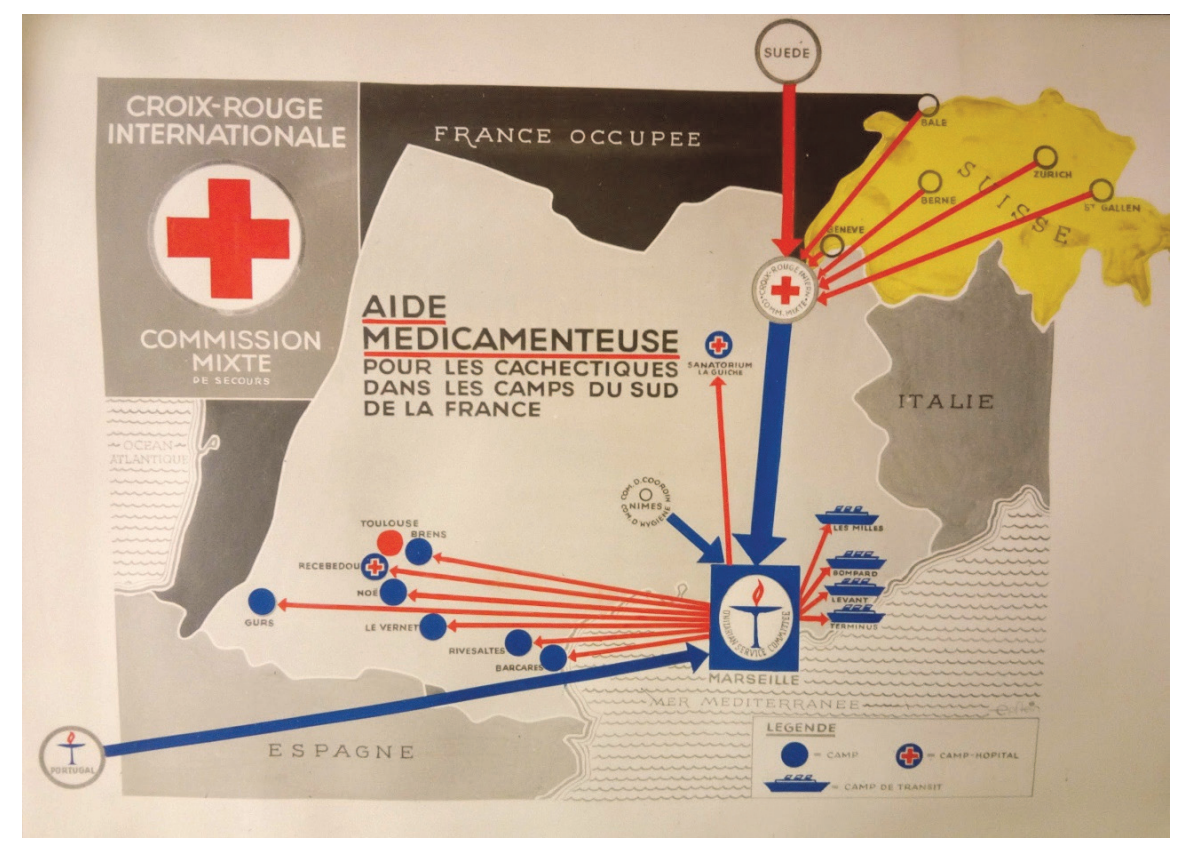

IMAGE 3. Humanitarian aid Map of the camps of southern France. Source: ACICR, O CMS D-114 


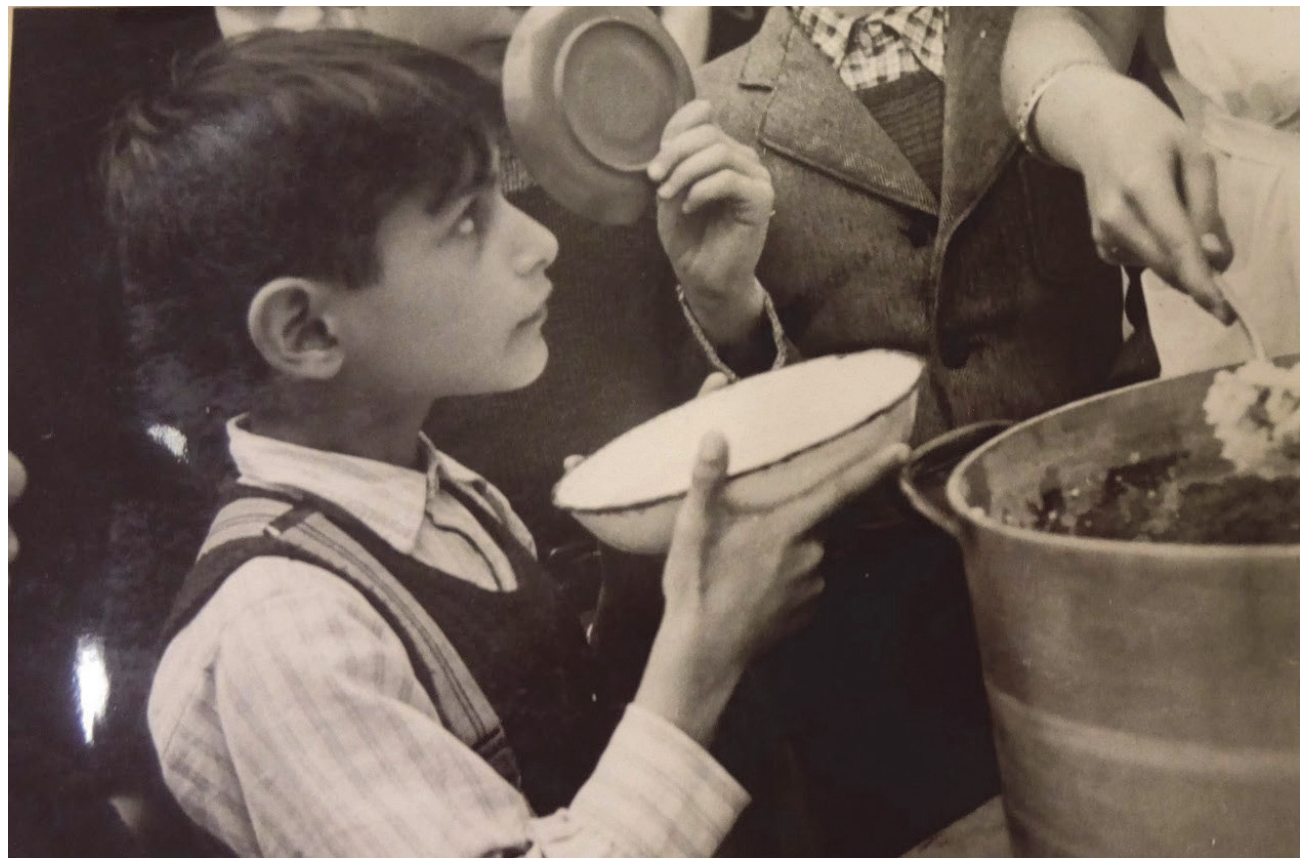

IMAGE 4. Food distribution in a French camp. Source: ACICR, O CMS D-114

\section{ACKNOWLEDGMENTS}

This article forms part of the project "European $\mathrm{Hu}$ manitarian Aid in France during the Second World War". Ref.: HAR2014-58043-P, Ministerio de Economía y Competitividad, Gobierno de España.

\section{NOTES}

1 CICR (1921a: 151-152).

2 Reinisch (2008: 373)

3 Barnett (2013: 383).

4 See Michael Barnett's contributions regarding humanitarianism and the types of intervention by humanitarian actors.

5 See Iriye (2002).

6 Bugnion (2002).

7 Pictet (1956: 7)

8 Rolland (1914).

9 CICR (1921a: 41-42, 129-136). For a more detailed analysis, see Becker (2012) and Stibbe (2006).

10 Convention IV (1907).

11 Abrisketa (2010: 47)

12 Lieber Code (1863).

13 Convention (1864).

14 Declaration of Saint Petersburg (1868).

15 Brussels Project (1874).

16 Oxford Manual (1880).

17 Convention II (1899).

18 Convention II (1899).

19 Schindler and Toman (1988: 63-99).

20 Plattner (1992).

21 CICR (1921b: 144).

22 American Society of International Law (1923: 250).

23 For more details on his figure, see Ferrière (1948).

24 Ferrière (1923: 565).

25 CICR (1923: 100).
26 CICR (1925); CICR (1928); CICR (1930a).

27 CICR (1934b).

28 CICR (1934a).

29 CICR (1938).

30 Schindler and Toman (1988: 223-229).

31 CICR (1930b: 681-724).

32 Durand (1998: 341).

33 ICRC (1948: 689-690).

34 Judt (2005: 16).

35 Federal Political Department (1950: 205-297).

36 Huber (1954: 117).

37 Procor (2010: 3-7).

38 Little (2014: 2).

39 Dombrowski Risser (2012: 271).

40 Paulmann (2013: 226).

41 Herrmann and Palmieri (2009); Herrmann (2012); Cotter and Herrmann (2014).

42 An analysis of the evolution and impact of wars upon the ICRC in Palmieri (2015).

43 Farré (2014: 126; 160).

44 CICR (1941: 3).

45 CICR (2016).

46 Durand (1983); CICR (1929: 185).

47 CICR, (1943: 321).

48 CICR (1942c: 564)

49 CICR (1948: 122-127).

50 Forsythe (2018: 61).

51 According to Brigitte Troyon and Daniel Palmieri, delegate is a unique term within international organizations, only employed by the ICRC. Troyon and Palmieri (2007).

52 Beaumont (2000: 57-82); for a broader perspective on the effects of the blockade in the occupied countries see Tönsmeyer, Haslinger and Laba (2018).

53 Zweig (1998: 850).

54 ACICR [Archives du Comité International de la Croix-Rouge], O CMS [Inventaire O CMS, Commission mixte de secours 1941-1948] O CMS B-033.

55 CICR (1942d: 4). 
$56 \operatorname{CICR}(1948: 127-129 ; 441)$.

57 CICR (1944: 10).

58 CICR (1946: 17).

59 ACICR, O CMS B-033.

60 ICRC (1948: 416).

61 ACICR, O CMS F-13.

62 ACICR, O CMS B-033.

$63 \operatorname{CICR}(1945: 3)$.

64 CICR (1948: 335-336).

65 Le Crom (2009: 151-157).

66 Le Crom (2005: 197).

67 CICR (1942a: 348-355); CICR (1942b: 516-521).

68 CICR (1948: 192-195).

69 ACICR, O CMS B-042.

70 ACICR, O CMS F-13.

71 ACICR, O CMS F-13.

72 CICR (1948: 210).

73 ICRC (1948: 554).

74 ACICR, O CMS B-033; ACICR, O CMS D-147.

75 Barnett (2018: 97).

76 Farré (2014: 155; 249).

77 Favez (1989: 48).

78 Farré (2014: 160; 249)

79 Favez (1989); Vonèche Cardia (2012).

80 Stibbe (2006).

\section{REFERENCES}

Abrisketa, Joana (2010) Derechos humanos y acción humanitaria. Zarauz, Alberdania.

American Society of International Law (1923) "General Report of the Commission of Jurists at The Hague". The American Journal of International Law, 4: 242-260.

Barnett, Michael (2013) "Humanitarian Governance". Annual Review of Political Science, 16: 379-398.

Barnett, Michael (2018) Empire of Humanity. A History of Humanitarianism. Cornell University Press, Ithaca and London.

Beaumont, Joan (2000) "Starving for Democracy: Britain's Blockade of and Relief for Occupied Europe, 1939-1945". War \& Society, 2 : 57-82.

Becker, Annette (2012) "Los dilemas de la protección de los civiles en los territorios ocupados: el ejemplo precursor de la Primera Guerra Mundial". International Review of the Red Cross, 885: 1-17. https://international-review.icrc.org/sites/default/files/irrc885-becker_0.pdf. [consulted 25/January/2018]

Bugnion, François (2002) "Homenaje a Jean Pictet". Revista Internacional de la Cruz Roja. https://www.icrc.org/spa/resources/ documents/misc/5tecbb.htm. [consulted 25/January/2018]

CICR (1921a) Rapport Général du Comité International de la Croix-Rouge sur son activité de 1912 à 1920. CICR, Genève.

CICR (1921b) Dixième Conférence Internationale de la Croix-Rouge. CICR, Genève.

CICR (1923) Onzième Conférence Internationale de la Croix-Rouge. CICR, Genève.

CICR (1925) Douzième Conférence Internationale de la Croix-Rouge. CICR, Genève.

CICR (1928) Treizième Conférence Internationale de la Croix-Rouge. CICR, La Haye.

CICR (1929) Treizième Conférence Internationale de la Croix-Rouge. Imprimerie Nationale, La Haye.

CICR (1930a) Quatorzième Conférence Internationale de la CroixRouge. CICR, Bruxelles.

CICR (1930b) Actes de la Conférence diplomatique convoquée par le Conseil fédéral suisse pour la révision de la Convention du 6 juillet 1906 pour l'amélioration du sort des blessés et malades dans les armées en campagne et pour l'élaboration d'une Convention relative au traitement des prisonniers de guerre et réunie à Genève du ler au 27 juillet 1929. CICR Genève.

CICR (1934a) Draft international Convention concerning the condition and the protection of civilians of enemy nationality in the territory of a belligerent or in a territory occupied by it. CICR, Geneva.

CICR (1934b) Quinzième Conférence Internationale de la CroixRouge. CICR, Tokyo.

CICR (1941) Action de la Commission Mixte de Secours de la Croix-Rouge internationale en faveur des Femmes et des Enfants victimes de la guerre. CICR, Geneva.

CICR (1942a) "A propos de l'action suisse de secours en faveur des enfants". Revue Internationale de la Croix-Rouge et Bulletin International des Sociétés de la Croix-Rouge, 281: 348-355.

CICR (1942b) "A propos de l'action suisse de secours en faveur des enfants". Revue Internationale de la Croix-Rouge et Bulletin International des Sociétés de la Croix-Rouge, 283: 516-521.

CICR (1942c) "Action de la Commission mixte de secours de la Croix-Rouge internationale en faveur des populations civiles, notamment des femmes et des enfants victimes de la guerre". Revue Internationale de la Croix-Rouge et Bulletin International des Sociétés de la Croix-Rouge, 284: 563-570.

CICR (1942d) L'ouvre de la Commission Mixte de Secours de la Croix-Rouge internationale en faveur des femmes et des enfants victimes de la guerre. CICR, Genève.

CICR (1943) "Commission mixte de secours de la Croix-Rouge internationale". Revue Internationale de la Croix-Rouge et Bulletin International des Sociétés de la Croix-Rouge, 292: 320-325.

CICR (1944) L'activité de la Commission mixte de secours de la Croix-Rouge internationale. CICR, Genève.

CICR (1945) La collecte de jouets. CICR, Genève.

CICR (1946) La Commission mixte de secours de la Croix-Rouge internationale. CICR, Geneva.

CICR (1948) Rapport de la Commission Mixte de Secours de la Croix-Rouge Internationale (1941-1946). CICR, Geneva.

CICR (2016) Principios fundamentales del Movimiento Internacional de la Cruz Roja y de la Media Luna Roja. Ética y herramientas para la acción humanitaria. CICR, Geneva.

Convention (II) with Respect to the Laws and Customs of War on Land and its annex: Regulations concerning the Laws and Customs of War on Land. The Hague, 29 July 1899. https://ihl-databases.icrc.org/ihl/INTRO/150?OpenDocument. [consulted 15/ October/2017].

Convention (IV) respecting the Laws and Customs of War on Land and its annex: Regulations concerning the Laws and Customs of War on Land. The Hague, 18 October 1907. https://ihl-databases.icrc.org/ihl/INTRO/195. [consulted 15/October/2017]

Convention for the Amelioration of the Condition of the Wounded in Armies in the Field. Geneva, 22 August 1864 https://ihl-databases.icrc.org/ihl/INTRO/120?OpenDocument. [consulted 15/ October/2017]

Cotter, Cédric and Herrmann, Irène (2014) "Les dynamiques de la rhétorique humanitaire : Suisse, États-Unis et autres neutres". Relations internationales, 159: 49-67.

Declaration Renouncing the Use, in Time of War, of Explosive Projectiles Under 400 Grammes Weight. Saint Petersburg, 29 November / 11 December 1868. https://ihl-databases.icrc.org/applic/ihl/ihl.nsf/Treaty.xsp?action=openDocument\&documentId $=3$ C02BAF088A50F61C12563CD002D663B. [consulted 15/ October/2017]

Dombrowski Risser, Nicole (2012) France under Fire. German Invasion, Civilian Flight, and Familiy Survival during World War II. Cambridge University Press, New York.

Draft Convention for the Protection of Civilian Populations Against New Engines of War. Amsterdam, 1938. https://ihl-databases. icrc.org/ihl/INTRO/345?OpenDocument. [consulted 15/October/2017]

Durand, André (1983) "Origin and Evolution of the Statutes of the International Red Cross". International Review of the Red Cross, 235: 175-208.

Durand, André (1998) Historia del Comité Internacional de la Cruz Roja. De Sarajevo a Hiroshima. Instituto Henry Dunant, Geneva.

Farré, Sébastian (2014) Colis de guerre. Secours alimentaire et organisations alimentaires (1914-1947). Presses Universitaire de Rennes, Rennes. 
Favez, Jean-Claude (1989) “1942: Le Comité international de la Croix-Rouge, les déportations et les camps". Vingtième siècle. Revue d'histoire, 21: 45-56.

Federal Political Department (1950) Final record of the diplomatic conference of Geneva of 1949. Vol. 1, Federal Political Department, Berne.

Ferrière, Adolphe (1948) Le Dr. Frédéric Ferrière : son activité à la Croix-Rouge Internationale en faveur des civiles victimes de la guerre. Suzerenne, Genève.

Ferrière, Frédéric (1923) "Projet d'une Convention internationale réglant la situation des civils tombés à la guerre au pouvoir de l'ennemi'. Revue Internationale de la Croix Rouge, 54: 560-585.

Forsythe, David P. (2018) "The International Red Cross: Decentralization and its Effects". Human Rights Quarterly, 1: 61-90.

Herrmann, Irène and Palmieri, Daniel (2009) "Le Comité International de la Croix-Rouge (CICR) et les camps de concentration Nazis, 1933-1939". Matériaux pour l'histoire de notre temps, 95: 65-74.

Herrmann, Irène (2012) "Décrypter la concurrence humanitaire: le conflit entre Croix-Rouge(s) après 1918". Relations internationales, 151: 91-102.

Huber, Max (1954) La pensée et l'action de la Croix-Rouge. CICR, Genève.

ICRC (1948) Report of the International Committee of the Red Cross on its activities during the Second World War (September 1, 1939 - June 30, 1947). Vol. I, ICRC, Geneva.

Instructions for the Government of Armies of the United States in the Field (Lieber Code). 24 April 1863. https://ihl-databases. icrc.org/applic/ihl/ihl.nsf/ART/110-20023?OpenDocument. [consulted 15/October/2017]

Iriye, Akira (2002) Global Community. The role of international organizations in the making of the Contemporary World. University of California Press, Berkley Los Angeles London.

Journal de Genève [JG] Rolland, Romain "Inter Arma Caritas", 4 Novembre 1914: 5.

Judt, Tony (2005) Postwar. A History of Europe Since 1945. Pimlico, London.

Le Crom, Jean-Pierre (2005) "Lutter contre la faim : le rôle du Secours national". In "Morts d'inanition». Famine et exclusions en France sous l'Occupation, edited by Von Bueltzingsloewen, Isabelle. Presse Universitaires de Rennes, Rennes: 196-207.

Le Crom, Jean-Pierre (2009) "La Croix-Rouge française pendant la Seconde Guerre Mondiale. La neutralité en question". Vingtième siècle. Revue d'histoire, 101: 149-162.

Little, Branden (2014) "An explosion of new endeavors: global humanitarian responses to industrialized warfare in the First World War era”. First World War Studies, 1: 1-16.
Palmieri, Daniel (2015) "How warfare has evolved-a humanitarian organization's perception: The case of the ICRC, 1863-1960". International Review of the Red Cross, 97: 985-998.

Paulmann, Johannes (2013) "Conjunctures in the History of International Humanitarian Aid during the Twentieth Century". $\mathrm{Hu}$ manity: An International Journal of Human Rights, Humanitarianism and Development, 2: 215-238.

Pictet, Jean (dir.) (1956) Les Conventions de Genève du 12 Août 1949. Commentaire. IV La Convention de Genève relative à la protection des personnes civiles en temps de guerre. CICR, Geneva.

Plattner, Denise (1992) 'L'assistance à la population civile dans le droit international humanitaire : évolution et actualité ". Revue Internationale de la Croix-Rouge, 795: 259-274, doi: 10.1017/ S0035336100104836.

Procor, Tammy M. (2010) Civilians in a World at War, 1914-1918. New York University Press, New York and London.

Project of an International Declaration concerning the Laws and Customs of War. Brussels, 27 August 1874. https://ihl-databases.icrc.org/applic/ihl/ihl.nsf/Treaty.xsp?action=openDocument \&documentId=42F78058BABF9C51C12563CD002D6659. [consulted 15/October/2017]

Reinisch, Jessica (2008) "Introduction: Relief in the Afetermath of War". Journal of Contemporary History, 3: 371-404.

Schindler, Dietrich and Toman, Jiří (eds.) (1988) The Laws of Armed Conflicts. A Collection of Conventions, Resolutions and other Documents. 3ed edition. Henry Dunant Institute, Geneva.

Stibbe, Matthew (2006) "The Internment of Civilians by Belligerent States during the First World War and the Response of the International Committee of the Red Cross". Journal of Contemporary History, 1: 5-19.

The Laws of War on Land. Oxford, 9 September 1880. https://ihldatabases.icrc.org/ihl/INTRO/140?OpenDocument. [consulted 15/October/2017]

Tönsmeyer, Tatjana; Haslinger, Peter and Laba, Agnes (editors) (2018) Coping with Hunger and Shortage under German Occupation in World War II. Palgrave Macmillan, London.

Troyon, Brigitte and Palmieri, Daniel (2007) "The ICRC delegate: an exceptional humanitarian player?" International Review of the Red Cross, 865: 97-111.

Vonèche Cardia, Isabelle (2012) Neutralité et engagement. Les relations entre le Comité international de la Croix-Rouge et le gouvernement suisse (1938-1945). SHSR, Lausanne.

Zweig, Ronald W. (1998) "Feeding the Camps: Allied Blockade Policy and the Relief of Concentration Camps in Germany, 1944-1945". The Historical Journal, 3: 825-851. 